\title{
Efek Serbuk Kunyit dan Kurkumin Terhadap Status Darah (Mus musculus L.) yang Diberi Minuman Beralkohol (Ciu)
}

\section{The Effect of Turmeric Powder and Curcumin on the Blood Status of (Mus musculus L.) which Were Given an Alcoholic (Ciu) Drink}

\author{
Fajriyah Rizki Nazila, Tyas Rini Saraswati*, Silvana Tana \\ Program Studi Biologi Fakultas Sains dan Matematika Universitas Diponegoro \\ *Email :Tyasrini63@gmail.com
}

Diterima 26 Juni 2020/Disetujui 28 Agustus 2020

\begin{abstract}
ABSTRAK
Kurkumin dalam kunyit mengandung atioksidan yang berpotensi memperbaiki gangguan eritropoiesis. Penelitian ini bertujuan untuk menguji pengaruh serbuk kunyit dan kurkumin terhadap status darah mencit (Mus musculus L.) yang diberi minuman beralkohol (ciu). Penelitian ini menggunakan Rancangan Acak Lengkap (RAL), dengan 20 ekor mencit jantan berbobot seragam yaitu $0.03 \mathrm{~kg}$, dibagi ke dalam 4 kelompok perlakuan dan 5 kali ulangan. R0 merupakan kontrol, R1 hanya diberi alkohol (ciu), R2 mencit yang telah diberikan alkohol (ciu) kemudian diberi serbuk kunyit, R3 mencit yang telah diberi alkohol (ciu) kemudian diberi serbuk kurkumin. Data dianalisis menggunakan uji ANNOVA, dilanjutkan uji Duncan pada taraf signifikasi 95\%. Hasil penelitian berbeda nyata $(\mathrm{P}<0.05)$ pada bobot badan dan tidak berbeda nyata $(\mathrm{P}>0.05)$ terhadap jumlah eritrosit dan kadar hemoglobin. Berdasarkan penelitian pemberian serbuk kunyit $0.1 \mathrm{~g}$ dan serbuk kurkumin $0.01 \mathrm{~g}$ belum mampu meningkatkan bobot badan, jumlah eritrosit dan kadar hemoglobin. akan tetapi berpotensi memperbaiki fungsi fisiologis dan metabolisme mencit.
\end{abstract}

Kata kunci: Ciu, Mus musculus L., bobot badan, leukosit, hemoglobin

\section{ABSTRACT}

Curcumin in turmeric contains antioxidants that have the potential to repair erythropoiesis demage. The Study aimed to examine the effect of turmeric powder and curcumin on the blood status of mice (Mus musculus L.) which were given the alcoholic drinks (Ciu). This study used a Completely Randomized Design (CRD), with 20 male mice uniformly weighted $0.03 \mathrm{~kg}$, divided into 4 control groups and 5 replications. R0 was a control, R1 was only given alcohol (ciu), R2 were mice that have been given alcohol (ciu) then given turmeric powder, R3 were mice that have been given alcohol (ciu) and then given curcumin powder. Data were analyzed using ANNOVA test, followed by Duncan test at 95\% significance level. The results of the study were significantly different $(\mathrm{P}<0.05)$ in body weight and not significantly different $(\mathrm{P}>0.05)$ on the number of erythrocytes and hemoglobin levels. Based on research giving $0.1 \mathrm{~g}$ turmeric powder and $0.01 \mathrm{~g}$ curcumin powder has not been able to increase body weight, the number of erythrocytes and hemoglobin levels. but improved physiological function and repaired of mice.

Keywords: Ciu, Mus musculus L., body weight, leukocyte, hemoglobin

\section{PENDAHULUAN}

Masyarakat Indonesia khususnya daerah Jawa masih banyak yang mengkonsumsi alkohol. Salah satu produk beralkohol yaitu ciu bekonang. Ciu Bekonang merupakan minuman tradisional khas Sukoharjo hasil fermentasi tetes tebu yang menghasilkan etanol dan karbondioksida dengan kadar etanol $\pm 30 \%$ (Hafizah dkk, 2012). Menurut
WHO (2011), Penyalahgunaan alkohol atau etanol menyebabkan kematian 2,5 juta setiap tahunnya di Dunia. Peminum alkohol di Indonesia pada tahun 2000, laki-laki sebanyak 35\%, dan wanita 9\% (Rehm, 2011). Pemerintah Provinsi DKI Jakarta juga menyatakan bahwa $90 \%$ kematian yang disebabkan minuman beralkohol karena mengkonsumsi oplosan (Deny, 2016). 
Mengkonsumsi alkohol dapat menyebabkan terjadinya gangguan kesehatan. Status kesehatan dapat diamati melalui status hematologi (Pearce, 2006).

Status hematologi dapat diamati melalui jumlah eritrosit dan kadar hemoglobin. Hati merupakan organ yang berperan dalam menghancurkan eritrosit yang sudah tua. Metabolisme alkohol menyebabkan peningkatan sintesis trigliserida, sehingga deposit trigliserida di dalam hati akan meningkat dan menyebabkan gangguan pada hati (Saraswati dkk., 2012). Hal ini akan mengganggu proses regulasi destruksi darah yang sudah tua di dalam hati, sehingga proses regulasi akan terhambat, karena pemecahan besi $\left(\mathrm{Fe}^{2+}\right)$ tidak dapat diserap kembali untuk pembentukan eritropoiesis dalam sumsum tulang (Bain, 2014). Kunyit merupakan salah satu tanaman obat yang berperan sebagai antitoksin, antioksidan, antiinflamasi, antibakteri dan sebagai hepatoprotektor. Kunyit memiliki kandungan zat aktif kurkumin dan minyak atsiri yang mampu meningkatkan penyerapan mineral dan berperan meningkatkan jumlah eritrosit dan melindungi hemoglobin dari oksidasi (Yuan dkk., 2018). Berdasarkan uraian diatas, maka perlu dilakukan penelitian untuk mendapatkan bukti pengamatan hematologis terhadap mencit (Mus musculus L.) jantan yang telah diberi alkohol (ciu) kemudian diberikan serbuk kunyit dan serbuk kurkumin.

\section{METODE PENELITIAN}

\section{Hewan Uji}

Hewan uji yang digunakan dalam penelitian ini adalah mencit jantan (Mus musculus L.) galur Swiss Webster jantan berumur 68 hari sebanyak 20 ekor dengan bobot seragam $0.03 \mathrm{~kg}$. Mencit diaklimatisasi pada kondisi laboratorium yang terkontrol selama 1 minggu kedepan pada setiap kandang peliharaan. Pakan standar dan minum tikus diberikan secara ad libitum.

\section{Alat dan Bahan Penelitian}

Bahan yang digunakan dalam penelitian ini adalah (Mus musculus L.) jantan 20 ekor, minuman beralkohol (Ciu), pakan standar (Pokphand B-82 P), air minum, serbuk kunyit dan serbuk kurkumin, aquades, HCL $0.1 \mathrm{~mL}$, larutan hayem, venoject dan gelas benda. Alat yang digunakan spuit injeksi $1 \mathrm{cc}$, gelas ukur, timbangan analitik, jarum berkanul, alat bedah, haemometer Sahli, pipet tetes, pipet Sahli, aspirator, bilik hitung improved neubaueur, pipet eritrosit, mikroskop dan counter.

\section{Perlakuan Hewan Uji}

Hewan uji diberikan perlakuan terlebih dahulu dengan alkohol (ciu) yang diberikan secara oral pada mencit menggunakan sonde yang telah disesuaikan dengan kapasitas volume lambung mencit, yaitu volume cairan $2 \mathrm{ml}$. Satu hari sekali pukul 16.00 selama 14 hari. Perlakuan hewan uji terdiri atas 4 kelompok perlakuan yaitu kelompok kontrol tampa perlakuan(R0); hanya diberikan alkohol (R1); mencit yang telah diberikan alkohol kemudian diberi larutan serbuk kunyit $0.1 \mathrm{~g}$ (R2); mencit yang telah diberikan alkohol kemudian diberi larutan kurkumin $0.01 \mathrm{~g}$ (R3). Pemberian perlakuan larutan serbuk kunyit dan kukumin diberikan setiap sore hari selama 30 hari. Dosis perlakuan diberikan sesuai dengan dosis yang telah dikonversikan pada bobot badan mencit. Seluruh mencit dibedah pada hari ke-30 kemudian darah di ambil dan ditampung kedalam venoject.

\section{Penentuan Jumlah Eritrosit}

Darah yang sudah dipersiapkan dihisap menggunakan aspirator sampai skala 0,1 pada pipet eritrosit. Larutan hayem dihisap menggunakan pipet yang sama sampai dengan skala 101 yang tertera pada pipet. Aspirator di lepaskan pada pipet. Kedua ujung pipet ditutup dengan ibu jari dan telunjuk tangan kanan, pipet di kocok secara perlahan dengan gerakan seperti angka 8 , sehingga yng tercampur hanya larutan yang berada pada bagian yang membesar saja (skala 1,0-101,0). Cairan yang tidak terkocok diujung pipet dibuang dengan menggunakan tissue dan kapas. Cairan kemudian dimasukan ke dalam bilik hitung yang telah dipersiapkan. Butir-butir darah merah kemudian dihitung dengan menggunakan teknik 5 bujur sangkar pada bujur sangkar besar di tengah 
kamar hitung.jumlah eritrosit yaitu jumlah semua darah merah pada kelima kotak bujur sangkar dikalikan 5000 butir (Bain, 2014).

\section{Penentuan Kadar Hemoglobin}

Darah dihisap perlahan-lahan dari tabung EDTA dengan pipet sahli menggunakan aspirator hingga batas skala $20(0,02 \mathrm{~mL})$. Darah yang berada pada ujung pipet dibersihkan dan segera darah dikeluarkan dengan ditiupkan darah dari pipet ke dalam tabung sahli. Semua darah di dalam pipet dimasukkan ke dalam tabung Sahli. Tabung Sahli diletakkan kembali diantara kedua bagian standar warna (blok komparator) dalam alat hemometer. Darah yang telah tercampur dengan larutan HCI 0,1 $\mathrm{N}$ didiamkan selama satu sampai tiga menit sampai terbentuk asam hematin yang berwarna cokelat. Aquades di tambahkan setetes demi setetes dengan menggunakan pipet tetes ke dalam tabung sahli sambil diaduk perlahan sampai warnanya sama dengan warna standar. Tinggi permukaan cairan darah pada tabung sahli dibaca dengan melihat skala yang berada pada tabung sahli (dengan satuan G\%) dan angka tersebut menunjukan kadar hemoglobin (Bain, 2014).

\section{Analisis Data}

Bobot badan, jumlah eritrosit dan kadar hemoglobin dianalisis menggunakan Uji ANNOVA kemudian jika terjadi perbedaan nyata dilakukan uji lanjut Duncan denga taraf kepercayaan $95 \%$ $(\alpha=0.05)$ (Pramesti, 2016).

\section{HASIL DAN PEMBAHASAN}

Hasil analisis pengaruh pemberian serbuk kunyit serta serbuk kurkumin terhadap status darah (Mus musculus L.) jantan yang diberi minuman beralkohol (ciu) yang dikelompokan menurut masing-masing perlakuan selama rentang waktu 30 hari menggunakan uji ANNOVA (analysis of variance) one way dengan taraf kepercayaan 95\% dapat dilihat pada Tabel 1. Hasil analisis bobot badan menunjukan perbedaann nyata $(\mathrm{P}<0.05)$, Menurut Widjaja dkk.,(2014) Konsumsi pakan mencit perhari 3-4 g/ hari. Terjadi penurunan
Hingga $\pm 4 x, \quad R 1$ jika dibandingkan dengan R0, penurunan yang signifikan dapat dilihat pada Gambar 1. Hal ini menunjukan karena terjadinya malnutrisi akibat pemberian minuman beralkohol (ciu) secara kronis pada mencit, alkohol (ciu) dapat menurunkan nafsu makan dan absorsi nutrien dalam proses pencernaan. Hasil penenelitian ini sesuai dengan Hazitilios et al. (2008) bahwa pada pasien yang mengkonsumsi alkohol (ciu) secara kronis menunjukkan terjadinya inflamasi sehingga terjadi iritasi pada organ pencernaan yang menyebabkan gangguan penyerapan transportasi nutrien, dan malnutrisi akibat gangguan metabolisme.

Gambar 1. Juga menunjukan pola yang berbeda antara bobot badan dengan konsumsi pakan. Hal ini menyebabkan mencit yang diberi suplemen serbuk kunyit dan kurkumin mengalami peningkatan konsumsi pakan yang lebih, tetapi belum berpengaruh terhadap bobot badan. Pemberian R1 dengan R2, R1 dengan R3 dan R2 dengan R3 tidak tedak terjadi perbedaan nyata $(\mathrm{P}>0.05)$ Hal ini diduga bahwa vitamin yang didapat melalui konsumsi dari pakan dan kunyit yang terabsorsi belum mampu meningkatkan proses metabolisme yang dapat meningkatkan bobot badan, namun energi yang dihasilkan dari proses metabolisme digunakan untuk recovery jaringan yang rusak untuk mencapai homeostatis dalam tubuh. Kunyit memiliki kandungan zat aktif yang dapat memperbaiki metabolisme tubuh antara kurkumin, minyak atsiri, dan mineral Fe. hal ini sesuai dengan Salama et al. (2013) kunyit mengandung zat aktif kurkumin dan minyak atsiri yang mampu meningkatkan penyerapan vitamin A, D, E, dan K.

Hasil analisis terhadap jumlah eritrosit tidak menunjukan perbedaan yang nyata $(\mathrm{P}>0.05)$. Eritrosit berperan dalam mengangkut oksigen $\left(\mathrm{O}^{2+}\right)$ dan karbon dioksida $\left(\mathrm{CO}^{2+}\right)$ didalam tubuh. jumlah eritrosit normal menurut Budiono (2008) ialah sekitar 4-7x10 $/ \mu 1$. R1 (mencit yang hanya diberi perlakuan alkohol (ciu) berdasarkan rata-rata berada dibawah normal. Hal ini diduga terjadi anemia gizi (nutrional anemia). Menurut Kiswari (2014) Anemia merupakan kondisi kurangnya sel darah merah (eritrosit) dalam tubuh, karena defisiensi zat besi $\left(\mathrm{Fe}^{2+}\right)$ dan rendahnya kadar 
hemoglobin dalam tubuh. Mencit yang diberikan alkohol secara kronis dapat mempegaruhi organ vital yaitu hati, dimana terjadinya peningkatan sintesis trigliserida dalam plasma hati dan meningkatkankan kadar laktat dalam darah, menyebabkan proses perombakan sel darah merah yang sudah tua di dalam hati terganggu (King,
2019). Hal ini akan mengganggu proses regulasi destruksi darah yang sudah tua didalam hati, sehingga proses regulasi akan terhambat karena proses pemecahan mineral besi $\left(\mathrm{Fe}^{+2}\right)$ dari darah yang sudah tua tidak bisa diserap kembali untuk pembentukan eritropoiesis dalam sumsum tulang (Bain, 2014).

Tabel 1. Hasil analisis rata-rata bobot badan, jumlah eritrosit dan kadar hemoglobin yang diberi minuman beralkohol (ciu) kemudian diberikan serbuk kunyit dan kurkumin.

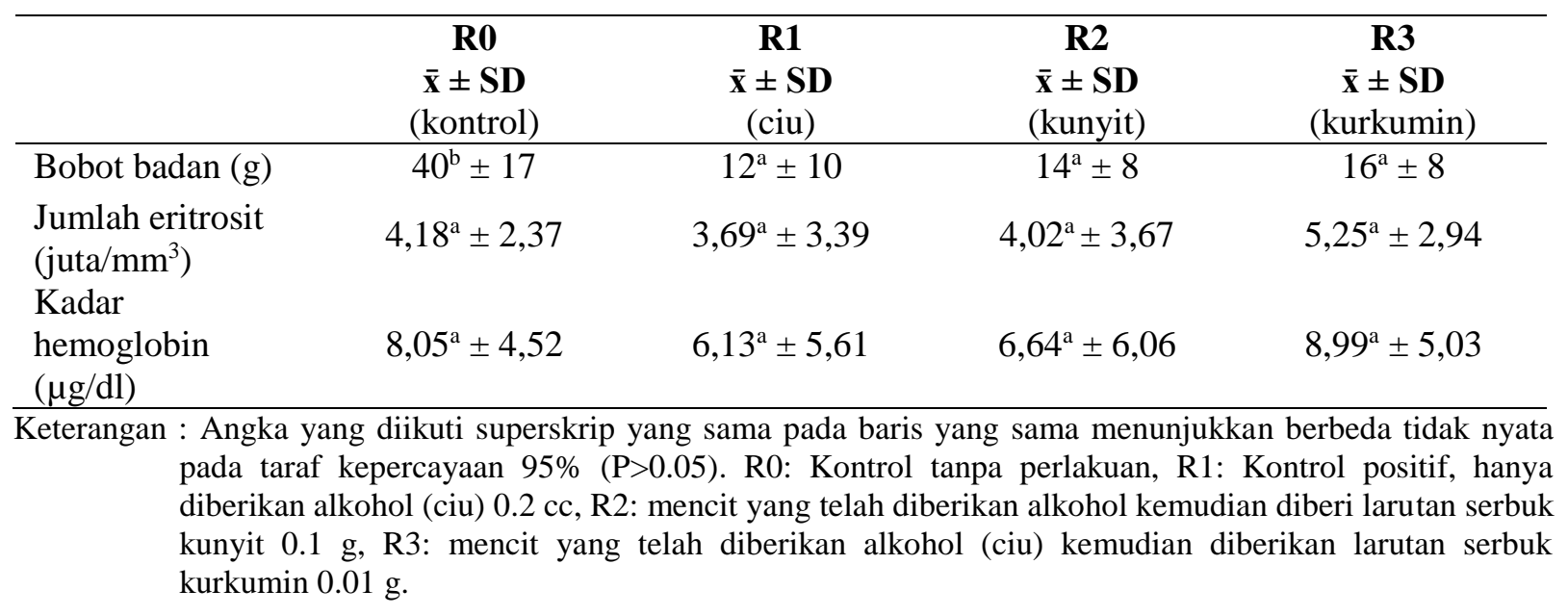
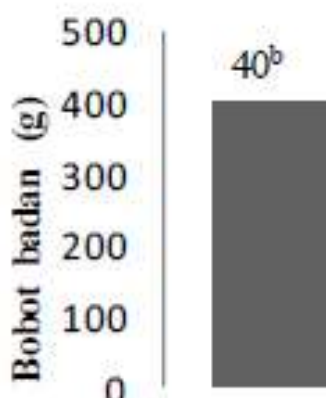

R0
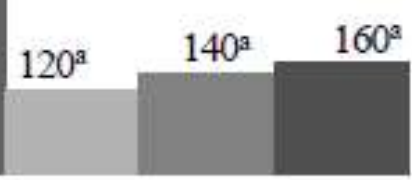

R1

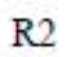

R3
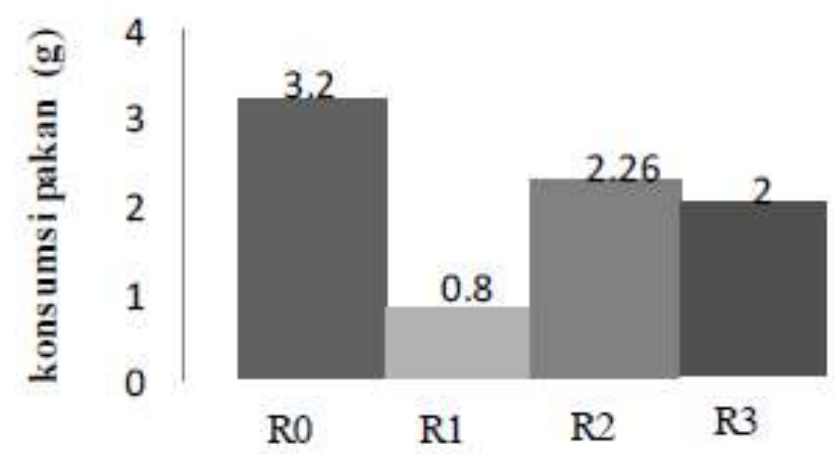

Gambar 1. Diagram batang pengaruh serbuk kunyit dan kurkumin terhadap bobot badan dan konsumsi pakan (Mus musculus L.)

Besi $\left(\mathrm{Fe}^{2+}\right)$ diperlukan untuk pembentukkan kompleks besi sulfur dan heme. R2 dan R3 berada pada rentang normal hal ini karena kunyit memiliki kandungan minyak atsiri, kurkumin, dan Fe serta mineral lain yang mampu membantu absorsi besi $\left(\mathrm{Fe} 2^{+}\right)$, hal ini sesuai dengan Salama et al. (2013), bahwa minyak atsiri mampu meningkatkan jumlah eritrosit dan melindungi hemoglobin dari oksidasi yang disebabkan alkohol karena mengandung seskuiterpen alkoholik. Meskipun uji analisis ANNOVA belum menunjukan hasil yang berbeda nyata namun apabila dilihat pada Gambar 2. Pemberian serbuk kunyit dan kurkumin menunjukan potensi kenaikan. Gangguan dalam pengikatan besi untuk membentuk hemoglobin mengakibatkan terbentuknya eritrosit dengan sitoplasma yang kecil (mikrosister) dan kurang mengandung hemoglobin didalamnya (hipokrom) 
sehingga pembentukan eritrosit dan biosintensis

hemoglobin terhambat (Murray et al., 2009)
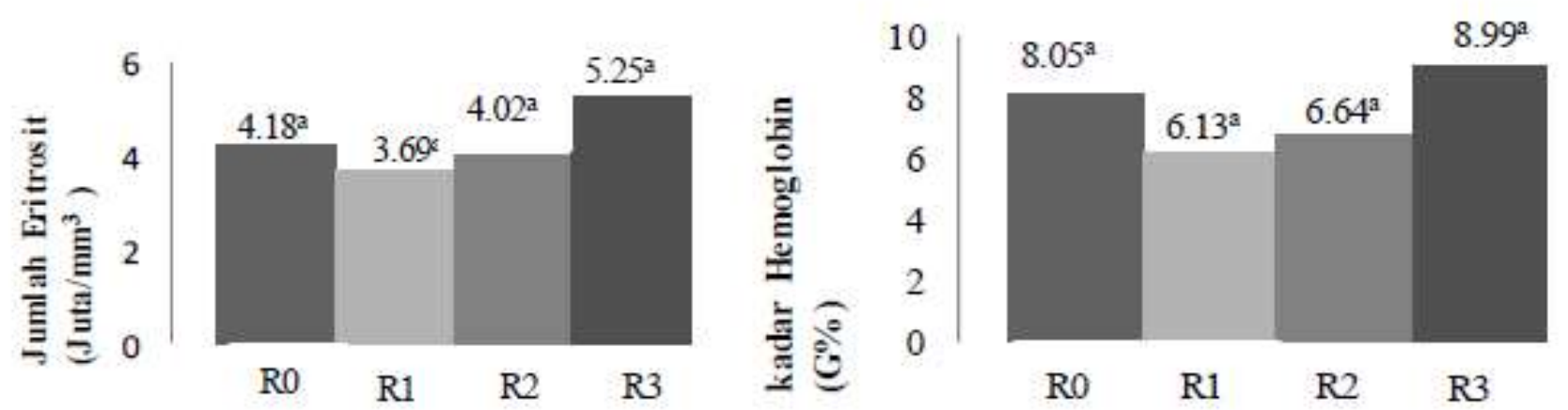

Gambar 2. Diagram batang hasil analisis pengaruh serbuk kunyit dan kurkumin terhadap jumlah eritrosit dan hemoglobin (Mus musculus L.)

Hasil analisis terhadap kadar hemoglobin tidak menunjukan perbedaan yang nyata $(\mathrm{P}>0.05)$, Hal ini menunjukkan bahwa pemberian serbuk kunyit dan serbuk kurkumin terhadap mencit yang telah diberikan alkohol (ciu) tidak mempengaruhi kadar hemoglobin, namun apabila dilihat Gambar 2. Meskipun uji analisis ANNOVA tidak menunjukkan perbedaan nyata, pemberian serbuk menunjukkan potensi kenaikan, yaitu dengan meningkatnya kadar hemoglobin yang dibandingkan dengan $\mathrm{R} 1$ dengan $\mathrm{R} 2, \mathrm{R} 1$ dengan R3, R2 dengan R3. Hasil pengukuran kadar hemoglobin juga menunjukkan pola yang sama dengan jumlah eritrosit. Hal ini karena kadar hemoglobin dipengaruhi oleh jumlah eritrosit. Etim et al. (2014) menyatakan bahwa hemoglobin dan eritrosit merupakan komponen hematologi. Kedua komponen tersebut dapat digunakan sebagai sarana pemeriksaan untuk mengetahui toksisitas suatu bahan yang mempengaruhi status kesehatan hewan. Menurut Benkociv et al. (2012) konsentrasi kadar hemoglobin pada Mus musculus L. normal ialah $8,77\left(10^{\mathrm{x}}\right)$. Mengkonsumsi alkohol secara kronis dapat meyebabkan Reactive oxygen Species (ROS) dan Reactive Nitrogen Oxigen Species (NOS). ROS dan NOS menyebabkan perubahan besi ferro $\left(\mathrm{Fe}^{2+}\right)$ menjadi besi ferri $\left(\mathrm{Fe}^{3+}\right)$ karena oksidasi. Ferri $\left(\mathrm{Fe}^{3+}\right)$ memiliki kelarutan lebih rendah pada $\mathrm{pH}$ normal sampai basa dibandingkan ferro $\left(\mathrm{Fe}^{2+}\right)$ sehingga ferri $\left(\mathrm{Fe}^{3+}\right)$ lebih sukar di absorsi hal ini dapat memicu methemoglobinemia, yaitu hemoglobin tidak mampu mengikat oksigen sehingga terjadi anemia sehingga kadar hemoglobin menjadi menurun (Murray et al., 2009). Hal ini juga didukung oleh Adam (2012) Alkohol memiliki efek metabolik pada enzim yang berperan pada jalur biosintesis heme. Efek metabolik ini menyebabkan penurunan sintesis heme sehingga akan menyebabkan penurunan sintesis hemoglobin. Menurut Kiswari (2014) sistesis hemoglobin dipengaruhi oleh keberadaan $\mathrm{Fe}$ dan protein. Kandungan $\mathrm{Fe}$ yang cukup tinggi pada serbuk kunyit dapat membantu peningkatan penyerapan Fe. Hal ini menurut Chattopadyay et al. (2004) Serbuk kunyit memiliki kandungan $\left(\mathrm{Fe}^{2+}\right)$ sebesar 1.4-1.5 mg/100 g. meskipun kunyit memiliki kandungan $\left(\mathrm{Fe}^{2+}\right)$ yang cukup banyak tetapi kandungan kurkumin dalam kunyit yang sedikit belum mampu melindungi hemoglobin dari oksidasi akibat pemberian alkohol secara kronis.

\section{KESIMPULAN}

Hasil penelitian menunjukan pemberian serbuk kunyit dengan kadar $0.1 \mathrm{~g}$ dan serbuk kurkumin dengan kadar $0.01 \mathrm{~g}$, belum mampu meningkatkan bobot badan, jumlah eritrosit dan kadar hemoglobin mencit (Mus musculus L.) yang sebelumnya telah diberi minuman beralkohol (ciu), akan tetapi berpotensi memperbaiki fisiologis dan metabolisme (Mus musculus L.) Perlu dilakukan penambahan dosis dan waktu perlakuan karena 
sudah mampu menunjukan efek peningkatan namun belum mampu meningkatkan bobot badan, jumlah eritrosit dan kadar hemoglobin.

\section{UCAPAN TERIMA KASIH}

Peneliti mengucapkan terima kasih kepada Pemberi dana PNBP Fakultas Sains dan Matematika dengan nomor kontrak: 38551/UN7.P4.3/PP/2018 yang sudah mensupport dana agar dapat terlaksana penelitian.

\section{DAFTAR PUSTAKA}

Adam, B. 2012. Purification Of Light Alcohols Using Macroporous Hydrophobic Membranes Chemistry. USA: Worcester Polytechnic Institute, Worcester.

Bain, J.B. 2014. Hematologi Kurikurum Inti. Jakarta: Buku Kedokteran EGC.

Budiono. 2008. Gambaran Darah Merah Kelinci yang Divaksin Ekstrak Caplak Rhipicephalus sanguinis. Skripsi. Institut Pertanian Bogor.

Bencociv, V., D. Dikic, T., Georgorinic, M. Mladinic, \& D.Z. Eljezic. 2012. Haematology and Blood Chemistry Changes in Mice Treated with Terbuthylazine and its Formulation Radazin TZ-50. Bull Environ Contam Toxicol. 89:955-959.

Deny, E. W. 2016. Hubungan antara Pengetahuan tentang. Risiko Kehamilan. Denpasar: Poltekkes.

Etim, N.N., M.E. Williams, U. Akpabio, E.E.A., \& Offiong. 2014. Haematological Parameters and Factors Affecting Their Values. Agricultural Science. 2(1): 37-47.

Hatzitolios, Tsiaous, Trygonis, \& Savopoulos. 2008. Malnutrition in end Stage Liver Disease. 23(4):33-527.

Hafizah, I., Sudayasa , I., Udu, W. S., J. B., M., \& Yakin, A. 2012. Pengaruh Minuman Tradisional Kameko Terhadap kadar SGOT, SGPT, dan Jaringan Hati Mencit (Mus musculus). Pharmauho, 23-25.
King, M. Ethanol metabolism. https://themedicalbiochemistrypage.org/etha nol-metabolism.php. Retrieved 11 April 2019.

Kiswari, Rukman .2014. Hematologi. Jakarta: EGC.

Murray, R., Granner, D., \& Rodwell, V. 2009. Biokimia Harper $(27$ ed). Jakarta: Buku Kedokteran EGC.

Pearce, E. 2006. Anatomi dan Fisiologi untuk Paramedis. Jakarta: Pustaka Gramedia.

Pramesti, Getut. 2016. Statistika Lengkap secara teori dan Aplikasi SPSS 23.0. Jakarta: PT Gramedia

Rehm, J. 2011. The risks associated with alkohol use and alkoholism. Alkohol Research \& Health, vol. 34:135-143.

Salama, S.M., Abdulla, M.A., AlRashdi, A.S., Ismail, S., Alkiyumi, S.S., and Golbabapour, S. 2013, Hepatoprotective effect of etanolic extract of Curcuma longa on thioacetamide induced livercirrhosis in rats. BMC: Complementary and Alternative Medicine, 13(56):1-17.

Saraswati, T.R.,, Praseno, K., \& Widowati, S. 2012. Pengaruh Tepung Kunyit (Curcuma longa L.) Terhadap Kadar Kolesterol dan Kadar Trigliserida Darah Burung Puyuh (Coturnix coturnix japonica L.). Jurnal biologi. Semarang: Universitas Diponegoro. (1):1.

Widjaja J., Tolistiawaty, I., Sumolang, P.P.F., \& Octaviani. Gambaran Kesehatan pada Mus musculus L. di Instalasi Hewan Coba. Jurnal Vektor Penyakit. Balai Litbang p2b2: Kementerian Kesehatan RI. 8(1):27-32.

World Health Organization (WHO). 2011. World Health Statistic. France: United Nations.

Yuan , S., Mardiati, S., \& Saraswati, T. 2018. Pertumbuhan Puyuh setelah Pemberian Tepung Kunyit pada Pakan. Buletin Anatomi dan Fisiologi, 22(2): 12-20. 